\title{
Temperature Gradient in the Earth's Crust.
}

SOME observations on temperatures in a deep borehole in South Africa were described by L. J. Krige and H. Pirow in June last before the Geological Society of South Africa. The bore-hole, which had been made in search of oil, is situated on the Dubbeldevlei Farm, near Carnarvon, at an elevation of about 3250 feet above sea-level. The country is flat and underlain by nearly horizontal strata assigned to the Ecca, Dwyka, and Fish River series. These rest upon granite and gneiss at a depth of 2687 feet. The borehole had been carried to a depth of 5080 feet, but the lower r6o feet had become silted up. The observations on temperature ranged from the surface down to a depth of 4912 feet, and were successfully made at 26 levels. Water stands in the hole at 32 feet from the surface. The upper $x$ Ioo feet of the hole is lined with $3 \frac{1}{2}$-inch casing. From I xoo feet to 3000 feet the diameter of the hole is $2 \frac{1}{1} \frac{\pi}{6}$ inches; it is then $2 \frac{1}{8}$ inches to 4500 feet, and $2_{1}^{1}$ inches from that point to the bottom.

The thermometers used were of the clinical type (that is, constricted between the bulb and the scale) and were enclosed in a brass tube 5 feet long and of $\mathrm{I} \frac{3}{4}$ inches external diameter. They were lowered by wires, and as a result of some preliminary experiments were left at the point of observation not less than four hours in order that the true temperature should be acquired. This seems a short time, but as a fact two readings made after $4 \frac{1}{4}$ hours and $\mathrm{I}_{1}^{\frac{1}{2}}$ hours respectively had been found to be identical.

The observations showed that the temperatures were affected by seasonal variations to a depth of 55 feet. Below this depth they ranged from $22 \cdot 25^{\circ} \mathrm{C}$. $\left(72.8^{\circ} \mathrm{F}\right.$.) at 75 feet depth to $69^{\circ} 75^{\circ} \mathrm{C}$. (I $57^{\circ} .5 \mathrm{~F}$.) at 4912 feet. They rose with depth at a maximum rate of increase of $\mathrm{I}^{\circ} \mathrm{C}$. in 60 feet in the upper part and at a minimum rate of $\mathrm{I}^{\circ} \mathrm{C}$. in $\mathrm{I} 4 \mathrm{O}$ feet in the lower part of the hole. Plotted graphically they form a curve of considerable regularity, but becoming steeper as the rate of increase decreases with increasing depth. The curve, however, shows certain irregularities which indicate that some other cause than increasing depth is affecting the rate of increase.

On associating the curve with a geological section of the bore-hole it becomes apparent that the irregularities, and indeed the curve itself, are determined by the relative conductivity of the strata traversed. Thus the upper part of the Ecca series is composed of shales of low conductivity; in these the rate of increase is uniform at $\mathrm{r}^{\circ} \mathrm{C}$. in 60 feet. The lower part of the series includes hard shales with calcareous nodules and a sheet of dolerite 135 feet thick; in these the rate varies from $x^{\circ} \mathrm{C}$. in 80 feet to $\mathrm{I}^{\circ} \mathrm{C}$. in roo feet. Below this, in another thick bed of shale in the Dwyka series, the rate rises to $\mathrm{I}^{\circ} \mathrm{C}$. in 85 feet, but still lower in the massive Dwyka tillite and sand- stone it falls to $\mathrm{I}^{\circ} \mathrm{C}$. in $\mathrm{r} 25$ feet. Again, in the Fish River series, it varies from $\mathrm{I}^{\circ} \mathrm{C}$. in 105 feet in sandstone and shale to $\mathrm{r}^{\circ} \mathrm{C}$. in 90 feet in some thick shales below. The lower part of the series consists of layers of shale mixed with grit and sandstone, and in these and the granite and gneiss on which they rest, the rate varied from $\mathrm{I}^{\circ} \mathrm{C}$. in $\mathrm{I} 20$ feet to $\mathrm{I}^{\circ} \mathrm{C}$. in $\mathrm{I} 70$ feet, the mean value being $\mathrm{I}^{\circ} \mathrm{C}$. in $\mathrm{I} 49$ feet. The highest rate in the granite and gneiss ( $\mathrm{I}^{\circ} \mathrm{C}$. in $\mathrm{r} 2 \mathrm{O}$ feet) was observed in a cavernous bed, the cavities in which were assumed to cause low conductivity.

In all cases the more rapid rates of increase are associated with the lower conductivities of the rocks, the badly conducting strata, or bands in the gneiss, acting as blankets. The worst conductor, as shown in a table published in the Report of the British Association for $\mathrm{I} 88 \mathrm{r}$, is shale, and among the best are quartzites, sandstones, dolerite, and granite; gneiss, limestones and soft sandstones occupy an intermediate place. All of these make their presence felt in the modifications of the curve of temperatures.

The author's remark that the measurement of underground temperatures and the calculation of the geothermic gradient have not much value if the nature and dip of the rocks pierced are not studied, seems to be well justified. Obviously an occasional observation, in place of a connected series, would be more likely than not to give a wrong impression of the gradient. In my own limited experience of such work the results were so far vitiated from this cause as to be useless. They were obtained in the Talargoch Leadmine in North Wales with all possible precautions, but showed $5^{\circ} \mathrm{F}$. difference at the same depth in different parts of the workings. I concluded that " the great differences in the rate of increase of temperature in different parts of the mine may perhaps be due to the very faulty nature of the ground. In some cases the rock overlying the point of observation was principally shale, in others limestone, in part thick-bedded and massive, in part thin-bedded and shaly " "The Geology of the Coasts adjoining Rhyl," etc., Mem. Geol. Survey, I885, p. 58). Many of the observations made in Great Britain have been carried out in shafts or bore-holes in Coal Measures, made up of numerous alternations of sandstone, shale, and clay, sometimes horizontal but more often inclined. Presumably the temperature-curve in such cases, if sufficiently detailed, would show a number of zig-zags, and it would be a matter of chance whether or not a correct conclusion could be drawn as to the general gradient.

The paper emphasises the difficulty of obtaining sufficiently accurate data for calculating the rate of increase of temperature in the crust of the earth from observations made in the thin film which alone is accessible to us.

\section{Radiography of Mummies.}

FOR the first time in America, X-ray photographs of mummies were taken recently. This has been made possible by a series of experiments begun at the Field Museum of Natural History, Chicago, and the satisfactory results already obtained will doubtless open a new and important field of operations in the scientific world.

The experiments were started by X-raying a group of Peruvian mummy packs from the Necropolis of Ancon. These had been collected for the World's Columbian Exposition, held in Chicago in 1893, and since have been in the possession of the Museum. To have unwrapped these mummy packs to ascertain whether they contained objects of special interest would have meant their destruction for exhibition purposes. By means of the X-ray pictures it is possible to learn what has been buried with the body, thus determining beforehand whether or not it be advisable to unwrap the bundle.

In the mummy packs thus far examined have been found ears of corn, pottery, vessels of clay containing shells, bits of metal, gourd vessels, beads, clay figurines, cut-bone objects-or, in some instances, nothing. In addition to the range of objects found NO. 284.3 , VOL. I I 3$]$ 
in the various bundles it is possible to gather something definite concerning the age, sex, and condition of the bony structure of the body buried therein. The nature of injuries received during the individual's life is sometimes revealed, and one can determine whether the deceased suffered from chronic rheumatism, tuberculosis of the bones, caries, arthritis of various kinds, and other diseases. In the Peruvian mummies thus far examined none of the trephining operations which were practised in Peru on its prehistoric inhabitants have been discovered.

In the Egyptian collections mummified cats, hawks, jackals, crocodiles, gazelles, and one mummy of a man of the 26 th dynasty, about 600 B.c., have been radiographed with very satisfactory results.

The mummy of a man was radiographed in five sections, beginning at the head, furnishing a very clear picture of the entire skeleton. Here we may expect to find fractures, pathological conditions such as bony tumours, rickets, hydrocephalus, pyorrhœa, and caries of the teeth, all of which have been shown in the examination of unwrapped skeletal material to have been common conditions of disease among Egyptians of the most ancient times.

In the picture of a hawk, even the tail feathers are very clearly shown. The picture of the mummy of a gazelle brings out the skeleton with remarkable distinctness; that of the crocodile also shows the bones still to be in their proper relative positions. The mummy of a jackal, which was wrapped with extreme care, is shown to contain slight traces of the bony structure of that animal, while the textile material within is in a condition which indicates that it had never been disturbed since its wrappings had been placed in position. In the case of the mummy of one cat exactly the opposite state was revealed.

Further investigations are to be made upon this same class of material as well as upon vessels made of marble, alabaster, and metal. Plans are also under way to extend the work of X-raying to several other departments of the Museum. The discoveries which will result will no doubt be of importance in various fields of scientific endeavour.

\section{University and Educational Intelligence.}

CAMBRIDGE.-A Busk Studentship in aeronautics has been established in memory of Edward Teshmaker Busk, who in r9I4 lost his life while flying the first stable aeroplane. The Studentship will be awarded for " research, or preparation for research in aeronautics and specially in those subjects such as stability problems, meteorological questions bearing on flight, or the investigation of gusts, treated either experimentally or mathematically, in which Edward Busk was specially interested." It is of the value of about I $5 \mathrm{ol}$, , tenable for one year, and may be extended for a second year. It is open to any man or woman, being a British subject and of British descent, who had not attained the age of twenty-five years on October I, 1923. Subject to the permission of the Trustees, the Student may carry out his research either at home or abroad. Inquiries relating to the Studentship should be addressed to Prof. B. M. Jones, Engineering Laboratory, Cambridge. Applications must be returned before May I2.

Durham.-So far back as I909, after the passing of the University of Durham Act, I908, the Durham County Council considered the advisability of suggesting to the Council of the Durham Colleges a joint conference of representatives of the University and of the County Council to discuss the question of securing some co-operation and co-ordination between the two bodies. This co-operation has now been secured, and a joint board consisting of an equal number of representatives from both bodies is to administer the Department of Education. In this way, it is hoped to effect co-ordination of the whole educational system of the County of Durham from the primary school to the University, and particularly to provide a steady supply of teachers with University qualifications. For this purpose, a School of Pure Science has been established, and Dr. Irvine Masson, reader in inorganic chemistry at University College, London, has been appointed professor of chemistry and director of the Science Department. The facilities afforded by the City of Durham in its provision of residential Colleges, the recent affiliation of Bede College and St. Hild's College to the University, and the establishment of the Neville's Cross College, give ground for confidence that the provision of further branches of study in addition to the ancient and flourishing School of Arts in the University will contribute both to the prosperity of the University and the higher education of the County at large. It is hoped that the first science students will be admitted in October next. The plans and specifications of the new buildings have been prepared under the personal supervision of Dr. W. N. Haworth, professor of organic chemistry in Armstrong College, Newcastle-upon-Tyne, and they include provision for the teaching and demonstration of chemistry, physics, geology, and botany.

LoNDON.-Among the public lectures for this term which have been arranged by University College are the following: "Some Questions concerning the Influence of Tropical Climate on Man," by Prof. C. Eijkman, of the University of Utrecht, on May 2, at 5 o'clock; "Positive and Negative Valences," by Prof. W. A. Noyes, of the University of Illinois, on May 5; "Kant's Theory of Beauty and Sublimity," by Prof. G. Dawes Hicks, on May I2, 19, and 26;" Sir Thomas Browne, author of the Religio Medici: His Skull and Portraits," by Miss M. Tildesley, on May 20 ; "On the Nature of Science," by Profs. A. N. Whitehead and T. Percy Nunn, on May 22 and 29 "Objective and Subjective Physics," by Prof. A. Haas, of the University of Vienna, on May 3o, at 5.I 5 "L'archéologie de la Syrie," by M. F. Cumont, on June 12,13 , and 16 . Public introductory lectures to courses include the following: "The Psychology of the Learning Process," by Mr. S. Philpott, on May $x$; and "Recent Discoveries in Egypt," by Sir Flinders Petrie, on May I5. Prof. R. A. Millikan, of the California Institute of Technology, Pasadena, U.S.A., is to deliver three public lectures on physics on June I3, I7, and I9. Except where otherwise stated, the lecture-hour is $5 \cdot 30$.

A course of three public lectures on "The PreCambrian, with special Reference to that of Ontario," will be given at the Imperial College, Royal School of Mines, by Dr. W. G. Miller, Provincial Geologist of Ontario, at 5.15 on Tuesdays, May $\mathrm{I}_{3}, 20$, and 27.

THE Secretary of the Smithsonian Institution at Washington announces that the time-limit for receiving applications for the Walter Rathbone Bacon Travelling Scholarship has been extended to June I. This scholarship, founded through a bequest from Mrs. Virginia Purdy Bacon, of New York, is for the "study of the fauna of countries other than the United States," the amount available being about 2400 dollars per year. Applications for the scholarship, addressed to the Secretary of the Smithsonian Institution, should contain a detailed plan for the proposed study, including a statement as to the

No. 2843 , VOL. I I 3$]$ 